\title{
Determination of crop-coefficients and estimation of evapotranspiration of rapeseed using lysimeter and different reference evapotranspiration models
}

\author{
ABHIJIT SARMA* and KRISHNA BHARADWAJ \\ Department of Agronomy, Assam Agricultural University, Jorhat, Assam, 785013 \\ *Corresponding author: abhijitaau@gmail.com
}

\begin{abstract}
Accurate estimation of evapotranspiration of rapeseed is essentially required for irrigation scheduling and water management. The present study was undertaken during 2015-16 and 2017-18 in ICR Farm, Assam Agricultural University, Jorhat to determine the crop coefficients (Kc) and estimate evapotranspiration of rapeseed using lysimeter and eight reference evapotranspiration models viz. Penman-Monteith, Advection-Aridity (Bruitsaert-Strickler), Granger-Gray, Makkink, Blaney-Criddle, Turc (1961), Hargreaves-Somani and Priestly-Tailor models. During 2015-16, the crop coefficients were developed by these models. Actual evapotranspiration was determined by three weighing type lysimeters. During 2017-18, evapotranspiration was estimated by multiplying reference evapotranspiration with Kc derived by different models and compared with actual evapotranspiration estimated by lysimeter during similar growing periods. All the models except Turc (1961) showed less than $10 \%$ deviation between actual and estimated ET. The estimated evapotranspiration using Penman-Monteith and Priestly-Tailor reference evapotranspiration recorded the lowest MAE and RMSE. The study revealed that estimated evapotranspiration using Penman-Monteith reference evapotranspiration gave the best estimate of evapotranspiration of rapeseed followed by Priestly-Tailor. The crop coefficients for initial, mid and end stages were $0.83,1.20$ and 0.65 , respectively for Penman-Monteith and 0.70, 1.05 and 0.55 , respectively for Priestly-Tailor.These results can be used for efficient management of irrigation water for rapeseed.
\end{abstract}

Keywords : Evapotranspiration, crop coefficient, rapeseed, reference evapotranspiration weighing lysimeter

Due to the scarcity of water resources, the correct evaluation of water losses by the crops as evapotranspiration is very important (Bhavsar and Patel, 2016).Plant water needs are estimated based on climatic parameters including air temperature, solar radiation, relative humidity and wind speed recorded by weather stations (Incrocci et al., 2014). These parameters help to determine the reference evapotranspiration (ET0) that can be calculated by many mathematical models. The actual crop evapotranspiration (ETc) determined using lysimeters and divided by reference evapotranspiration $\left(\mathrm{ET}_{0}\right)$ is defined as crop coefficient $(\mathrm{Kc})$. The crop coefficient $(\mathrm{Kc})$ value represents crop-specific water use and is required for accurate estimation of irrigation requirement of different crops grown under different climatic conditions (Doorenbos and Pruitt, 1977). Development of crop coefficient $(\mathrm{Kc})$ for rapeseed is important to accurately determine irrigation water requirements of the crop. Using lysimeters to measure crop water use and prescribed methods to compute reference evapotranspiration rates, the crop coefficients can be calculated on a daily basis; and averaged on a monthly basis, for practical use when calculating irrigation requirements. The adoption of the exact or correct amount of water and correct timing of application is very essential for scheduling irrigations to meet the crop's water demands and for optimum crop production (Mehta and Pandey, 2016). On average, obtaining a better understanding of the actual crop water requirement based on modern technologies could save at least $50 \%$ of irrigation water (Ragab et al., 2017). Among the empirical models, the Food and Agricultural Organization hasrecommended the PenmanMonteith equation (FAO-PM) asa standard method for ET estimation (Allen et al., 1998). FAO- PM equation requires meteorological parameters such astemperature, humidity, wind speed, sunshine hours and net radiation to determine ET. Empirical models like Hargreaves-Somani, Turc,BlaneyCriddle etc., have also been used by several working as they require less number of meteorological parameters (Dar et al., 2017; Phad et al., 2019). As such, it is required to develop Kc values for different models for the estimation of evapotranspiration. Based on the above, this experiment was undertaken in order to determine the crop coefficients $(\mathrm{Kc})$ and estimate evapotranspiration of rapeseed using eight reference evapotranspiration models. 


\section{MATERIALS AND METHODS}

\section{Location of experiment}

The experiment was conducted at Instructional-cumResearch (ICR) Farm, Assam Agricultural University, Jorhat13 during 2015-16 and 2017-18. The ICR Farm is situated at $26^{\circ} 47^{\prime} \mathrm{N}$ latitude, $94^{\circ} 12^{\prime} \mathrm{E}$ longitude and at an altitude of 87.0 metres above mean sea level. The climatic condition of Jorhat is subtropical humid with hot summer and cold winter. The average annual rainfall is $1864.8 \mathrm{~mm}$. Out of this, $1194.8 \mathrm{~mm}, 467.1 \mathrm{~mm}, 151.4 \mathrm{~mm}$ and $51.5 \mathrm{~mm}$ are received during monsoon, pre-monsoon, post-monsoon and winter, respectively. The minimum monthly temperature of $9.7^{\circ} \mathrm{C}$ and maximum monthly temperature of $32.4^{\circ} \mathrm{C}$ are observed in January and August, respectively. During January and March, maximum (morning) and minimum (evening) monthly relative humidity of $94.8 \%$ and $61.1 \%$, respectively are observed (Sarma and Das, 2017).

\section{Measurement of actual evapotranspiration}

The components of the water balance equations were measured by 3 weighing type lysimeters with dimensions of $1.3 \mathrm{~m} \times 1.3 \mathrm{~m} \times 0.9 \mathrm{~m}$ each. Each lysimeter was filled up with soil and rapeseed was grown. Fertilizers were applied as basal @ 60-40-40 kg N- $\mathrm{P}_{2} \mathrm{O}_{5}-\mathrm{K}_{2} \mathrm{Oha}^{-1}$ in the form of urea, SSP and MOP, respectively. The texture of the soil was sandy loam and acidic ( $\mathrm{pH} 5.1$ ) in nature. The field capacity of the soil was found to be $25.9 \%$ and the permanent wilting point was $8.92 \%$. The rapeseed variety TS 38 was sown on 30 October, 2015 and 30 October 2017 during the first and second year, respectively maintaining a spacing of $30 \mathrm{~cm}$ between row to row and $5-7 \mathrm{~cm}$ between plant to plant. During 2016, the experiment could not be conducted as the lysimeters were used for another experiment. The crop was harvested on 31 January, 2016 and 31 January, 2018. The same variety of rapeseed crop was sown inside and outside the lysimeters to eliminate boundary effects. Fluctuations in weight of lysimeters were recorded at 8.30 a.m. everyday and daily loss of weight was replenished by irrigation. During 2015-16 and 2017-18, $81.10 \mathrm{~mm}$ and $24.40 \mathrm{~mm}$ rainfalls were received.

Actual evapotranspiration of rapeseed was measured using the soil water balance equation. The water balance equation can be expressed as follows:

$$
\mathrm{ET}=\mathrm{P}+(\mathrm{I}-\mathrm{D})+\mathrm{S}
$$

Where, $\mathrm{ET}=$ Evapotranspiration; $\mathrm{P}=$ Precipitation; $\mathrm{I}=$ Irrigation water; $\mathrm{D}=$ Excess water drained from the bottom; $\mathrm{S}=$ Increase or decrease in the storage of soil moisture

Change in soil moisture $(\mathrm{S})$ is the difference in the moisture content of each consecutive days and it was calculated by deducting the moisture content of the day from the previous day starting from sowing to the last harvest. The drained outwater accumulated at the bottom tank of the lysimeter. This water was pumped out with the help of a pedal pump and the volume was measured. Dividing the volume by the area of the lysimeter, drainage depth of water was calculated.

\section{Estimation of ET $T_{0}$ by different models}

The reference evapotranspiration $\left(\mathrm{ET}_{0}\right)$ was estimated by Penman-Monteith, Advection-Aridity (BruitsaertStrickler), Granger-Gray, Makkink, Blaney-Criddle, Turc (1961), Hargreaves-Somani and Priestly-Tailor models (Table 1).

\section{Calculation of crop coefficient (Kc)}

The crop coefficient is defined as the ratio of crop evapotranspiration to the reference crop evapotranspiration. During 2015-16, the crop coefficient (Kc) was determined by the following equation:

$\mathrm{K}_{\mathrm{c}}=\mathrm{ET}_{\mathrm{c}} / \mathrm{ET}_{0}$

Where, $\mathrm{ETc}=$ Measured actual crop evapotranspiration; ET0 $=$ Reference crop evapotranspiration

The entire crop period of rapeseed was divided into four sub-periods viz. initial period (1-13 DAS); development period (14-33 DAS); mid-period (34-65 DAP); and late period (66-93 DAP). The crop coefficients for initial (Kc ini), $\operatorname{mid}(\mathrm{Kc} \mathrm{mid})$ and end (Kc end) periods for different models viz. Penman-Monteith, Advection-Aridity (BruitsaertStrickler), Granger-Gray, Makkink, Blaney-Criddle, Turc (1961), Hargreaves-Samani and Priestly-Tailor were determined from Fig. 1.

The crop coefficients of the development and late periods were determined by the following equation (Allen $e t$ al., 1998):

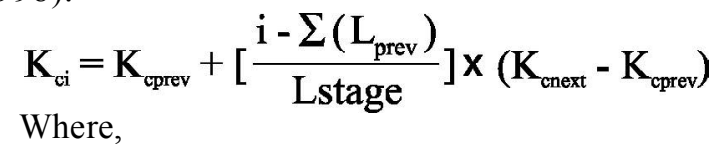

$\mathrm{Kci}=$ Kcon day ' $\mathrm{i}$ ' $; \mathrm{i}=$ Daynumber within the growing season; Kcprev $=\mathrm{Kc}$ of the previous stage; $\mathrm{Kcnext}=\mathrm{Kc}$ of the next stage 
Table 1: Various model used for computing ET0

\begin{tabular}{|c|c|c|}
\hline Model & Formula & Reference \\
\hline Penman-Monteith & $\frac{0.404 \Delta\left(R_{n}-\mathrm{G}\right) \frac{900}{\mathrm{~T}+273} \mathrm{u}_{2}\left(\mathrm{e}_{\mathrm{s}}-\mathrm{e}_{\mathrm{a}}\right)}{+\left(1+0.34 \mathrm{U}_{2}\right)}$ & Allen et al., 1998 \\
\hline $\begin{array}{l}\text { Advection-Aridity } \\
\text { (Bruitsaert-Strickler) }\end{array}$ & $\left(2 \propto_{P T}-1\right) \frac{\Delta}{\Delta+} \frac{R_{n}}{\lambda}-\frac{\Delta}{\Delta+} f\left(u_{2}\right)\left(\mathrm{e}_{s}-\mathrm{e}_{\mathrm{a}}\right)$ & Brutsaert and Strickler, 1979 \\
\hline Granger-Gray & $\frac{\Delta G_{g}}{\Delta G_{g}+}-\frac{R_{n}-G}{\lambda}+\frac{\Delta G_{g}}{\Delta G_{g}+} E_{a}$ & Granger and Gray, 1989 \\
\hline Makkink & $0.61\left[\frac{\Delta}{\Delta+2.45} \frac{R_{S}}{2.4}-0.12\right]$ & de Bruin, 1981 \\
\hline Blaney-Criddle & $\begin{array}{c}\left(0.0013 R H_{\min } n N-1.11\right)+b_{v a r} P_{y}\left(0.16 T_{a}+8.13\right) \\
b_{v a r}=e_{0}+e_{1} R H_{\min }+e_{2} \frac{n}{N}+e_{3} u_{2}+e_{4} R H_{\min } \frac{n}{N} \\
+e_{5} R H_{\text {min }} u_{2}\end{array}$ & Allen and Pruitt, 1986 \\
\hline Turc (1961) & $0.013\left(23.88 R_{s}+50 \frac{T_{a}}{T_{a}+15}\right.$ & Turc, 1961 \\
\hline Hargreaves-Somani & $0.0135 C_{H S} \frac{R_{a}}{\lambda}\left(T_{\max }-T_{m i n}\right)^{0.5}\left(T_{a}+17.8\right)$ & Hargreaves and Somani, 1985 \\
\hline Priestly-Tailor & $\propto_{P T}\left[\frac{\Delta}{\Delta+} \frac{R_{n}}{\lambda}-\frac{G}{\lambda}\right]$ & Priestley and Taylor, 1972 \\
\hline
\end{tabular}

$\alpha \mathrm{PT}=$ Priestly Tailor parameter; $\Delta=$ Slope of the saturated vapour pressure at air temperature $\left(\mathrm{kPa} /{ }^{\circ} \mathrm{C}\right) ; \mathrm{Rn}=\mathrm{Net}$ radiation $(\mathrm{MJ} /$ $\mathrm{m} 2 /$ day); $\Upsilon=$ Psychrometric constant $\left(\mathrm{kPa} /{ }^{\circ} \mathrm{C}\right) ; \lambda=$ Latent heat of vaporization $(\mathrm{MJ} / \mathrm{kg}) ; \mathrm{u}_{2}=$ the average daily wind speed $(\mathrm{m} / \mathrm{s})$; es = Saturation vapour pressure $(\mathrm{kPa})$; ea $=$ Actual vapour pressure $(\mathrm{kPa}) ; \mathrm{f}(\mathrm{u} 2):$ Penman (1948) wind function; aPT = Priestley-Taylor constant (1.26 for "advection-free" saturated surfaces); $\mathrm{Gg}=$ a dimensionless evaporation parameter; Ea= Drying power of the air; Rs = Incoming shortwave solar radiation (MJ/m2/day); RHmin= Minimum relative daily humidity (\%); $\mathrm{n} / \mathrm{N}=$ Measured sunshine hours divided by the possible daily sunshine hours; Py = Percentage of actual daytime hours for the day compared to the day-light hours for the entire year; $\mathrm{Ta}=$ the average daily air temperature $(\mathrm{oC}) ; \mathrm{u}_{2}=$ Average daily wind speed $(\mathrm{m} / \mathrm{s})$ at $2 \mathrm{~m} ; \mathrm{e}_{0}=0.81917 ; \mathrm{e}_{1}=-0.0040922 ; \mathrm{e}_{2}=1.0705 ; \mathrm{e}_{3}=0.065649 ; \mathrm{e}_{4}=-0.0059684 ; \mathrm{e}_{5}=-0.0005967 ;$ CHS $=$ Emperical constant; $\operatorname{Tmax}=$ Maximum average daily temperature $\left({ }^{\circ} \mathrm{C}\right) ; \operatorname{Tmin}=$ Minimum average daily temperature $\left({ }^{\circ} \mathrm{C}\right) ; \mathrm{Ra}$ $=$ Extraterrestrial radiation $(\mathrm{MJ} / \mathrm{m} 2 /$ day $)$

$\Sigma\left(\mathrm{L}_{\text {prev }}\right) \quad=$ Sum of the lengths of all previous stages (days)

$\mathrm{L}_{\text {stage }}=$ Length of the stage under consideration (days)

\section{Estimation of evapotranspiration (Est Etc)}

Evapotranspiration of rapeseed under the climatic condition of Jorhat was estimatedby multiplying the calculated reference evapotranspiration of 2017-18 with Kcderived in 2015-16 by different models during the similar growing period.

\section{Comparison of different models}

During 2017-18, actual evapotranspiration (ETc) was measured using lysimeter and estimated evapotranspiration (Est ETc) for the same period using different models was compared with average error (AE), mean absolute error (MAE), mean bias error (MBE) and root mean square error (RMSE). These were calculated as follows:

$$
\begin{aligned}
A E & =\frac{E s t E T_{c}-E T_{c}}{E T_{c}} \times 100 \% \\
M A E & =\sum_{i=1}^{n}\left[\left|E s t E T_{c}-E T_{c}\right|\right] / n \\
M B E & =\sum_{i=1}^{n}\left[E s t E T_{c}-E T_{c}\right] / n \\
R M S E & =\left[\sum_{i=1}^{n}\left[E s t E T_{c}-E T_{c}\right]^{2} / n\right]^{1 / 2}
\end{aligned}
$$

Where, $\mathrm{n}=$ number of observation 


\section{RESULTS AND DISCUSSION}

\section{Crop coefficients of different models}

The crop coefficients of rapeseed developed by lysimeter experiment during 2015-16 for initial (Kc ini), mid (Kc mid) and end period (Kc end) by different models using Fig. 1 are presented in Table 2. The Kc values integrate the effect of characteristics that distinguish a typical field crop from the grass reference, which has a constant appearance and a complete ground cover. The changing characteristics of the crop over the growing season have an effect on the Kc.In the study, the crop coefficients were lowest in the early crop growth period, gradually increased and reached a peak during 34-65 DAS and then decreased. At the last, the crop coefficient value decreased steadily due to maturity and senescence of leaf. Allen et al. (1998) also found that the crop coefficient depended on the type of crop, its stageof growth, canopy cover and crop density.

In all the models except Blaney-Criddle, Kc mid recorded the highest values indicating highest evapotranspiration during the mid-period of growth followed by Kc ini. The Kc mid values for Penman-Monteith, GrangerGray and Makkink models were higher than 1.0 which indicated higher ETc than estimated ET0 under these models during the mid-period. The leaf area index, wind turbulence and leaf temperature are possible reasons for the increase in crop requirement above reference evapotranspiration (Kokilavani et al., 2018). The lowest value was recorded for $\mathrm{Kc}$ end. The developed Kc ini, Kc mid and Kc end values for Penman-Monteith were 0.83, 1.20 and 0.65. Granger-Gray model recorded higher Kc ini value than the PenmanMonteith model; however, Kc midvalue was equal to PenmanMonteith. Other models recorded lower Kc ini values than Penman-Monteith. Granger-Gray, Makkink and BlaneyCriddle models recorded slightly higher Kc end values. Kc end values for the rest of the models were smaller than the Penman-Monteith model.This variation is due to the differences in the estimation of reference evapotranspiration by different models. Tahashildar et al. (2017) also observed wide variations of reference evapotranspiration estimated by different empirical models inthe mid-hill region of Meghalaya.

\section{Comparison of estimated evapotranspiration derived from different methods}

Estimated evapotranspiration (Est ETc) of rapeseed during 2017-18 using the reference evapotranspiration and crop coefficients developed by different models during
2015-16 indicated slight average error from actual evapotranspiration (ETc) (Table 3). The ETc of the crop during the initial, development, mid and late periods were $27.90 \mathrm{~mm}, 36.90 \mathrm{~mm}, 61.86 \mathrm{~mm}$ and $42.41 \mathrm{~mm}$, respectively with a total of $169.13 \mathrm{~mm}$. The total ET loss estimated throughthe Penman-Monteith method for rapeseed during the entire season of the crop was $168.86 \mathrm{~mm}$ with $-0.16 \%$ average error.In case of other models, the sum total ET losses were found to be $159.54 \mathrm{~mm}, 158.17 \mathrm{~mm}, 170.28 \mathrm{~mm}$, $159.37 \mathrm{~mm}, 151.59 \mathrm{~mm}, 167.45 \mathrm{~mm}$ and $171.44 \mathrm{mmwith}$ average error of $-5.67 \%,-6.47 \%, 0.68 \%,-5.77 \%,-10.37 \%$, $-0.99 \%$ and $1.37 \%$ usingAdvection-Aridity (BruitsaertStrickler), Granger-Gray, Makkink, Blaney-Criddlel,Turc (1961), Hargreaves-Samani and Priestly-Tailor models, respectively.Thus all the models except Turc (1961) showed less than $10 \%$ deviation between actual and estimated ET. Penman-Monteith slightly underestimatedand Makkink and Priestly-Tailor models slightly overestimated the evapotranspiration. Contrary to it, Prajapati and Subbaiah (2019) found that adjusted FAO Kc overestimated evapotranspiration in Bt cotton in Junagadh. It suggested that local variability of meteorological conditions is important for estimation of reference evapotranspiration by different models. In the present study, the Penman-Monteith, Makkink and Priestly-Tailor models were also very consistent in different growth stages (except for developmental period) with average error within $+1.5 \%$. Bhat et al. (2017) found that Makkink model fits best with the Penman-Monteith model and it was followed by Priestley-Taylor. Khavse et al. (2017) also found the Penman-Monteith model to be more appropriate as this method is rationalizing the weightage factor of different meteorological parameters.

The performance of the model was evaluated in termsof error analysis (Table 4). The ET estimated using Penman-Monteith and Priestly-Tailor reference evapotranspiration recorded the lowest MAE and RMSE indicating the lowest magnitude of average error. This can be attributed to the fact that the Penman-Monteith model takes into consideration both radiation as well as aerodynamic components in the estimation of evapotranspiration (Allen et al., 1998). Tomar (2016) found that the Priestley-Taylor method could estimate compatible ET0 values as estimated by the Penman-Monteith method.

The estimated ET using Penman-Monteith reference evapotranspiration also recorded thelowest deviation (0.003 ) in terms of MBE followed by ET estimated through Makkink (0.01), Priestly-Tailor (0.02) and Hargreaves- 

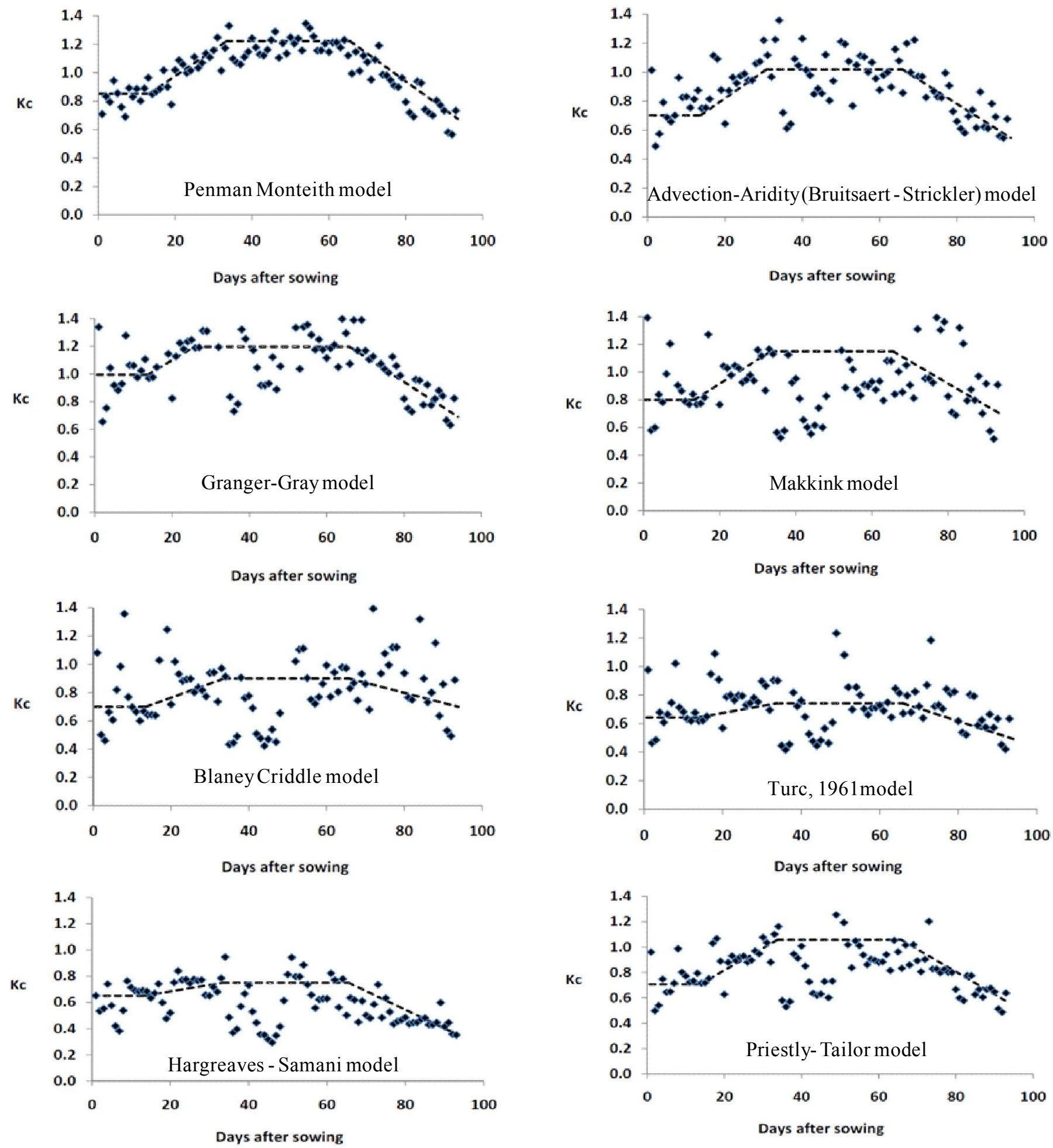

Fig. 1: Crop coefficient of rapeseed developed with different models

Somani (-0.02) reference evapotranspiration. As such, estimated ET using Penman-Monteith and HargreavesSomani underestimate the crop evapotranspiration by 0.003 mmday $^{-1}$ and $0.01 \mathrm{mmday}^{-1}$. On the other hand estimated ET using Makkink and Priestly Tailor overestimate the crop evapotranspiration by $0.01 \mathrm{mmday}^{-1}$ and $0.02 \mathrm{mmday}^{-1}$. Naiduand Majhi (2019) observed large deviations of Hargreaves, Turc and Blaney-Criddlereference evapotranspiration from Penman-Monteith reference evapotranspiration 
Table 2: Crop coefficients of rapeseed developed by lysimeter experiment for initial, mid and end period using different models during 2015-16

\begin{tabular}{lllllllll}
\hline $\begin{array}{l}\text { Crop } \\
\text { coefficient }\end{array}$ & $\begin{array}{l}\text { Penman } \\
\text { Monteith }\end{array}$ & $\begin{array}{l}\text { Advection- } \\
\text { Aridity } \\
\text { model }\end{array}$ & $\begin{array}{l}\text { Granger- } \\
\text { Gray } \\
\text { model }\end{array}$ & Makkink & $\begin{array}{l}\text { Blaney- } \\
\text { Criddle }\end{array}$ & $\begin{array}{l}\text { Turc } \\
(1961)\end{array}$ & $\begin{array}{l}\text { Hargreaves- } \\
\text { Samani }\end{array}$ & $\begin{array}{l}\text { Priestly- } \\
\text { Tailor }\end{array}$ \\
\hline Kc ini & 0.83 & 0.70 & 1.00 & 0.80 & 0.70 & 0.60 & 0.65 & 0.70 \\
Kc mid & 1.20 & 1.00 & 1.20 & 1.15 & 0.90 & 0.75 & 0.75 & 1.05 \\
Kc end & 0.65 & 0.55 & 0.70 & 0.70 & 0.70 & 0.50 & 0.35 & 0.55 \\
\hline
\end{tabular}

Table 3: Actual ET and estimated ET of rapeseed using the reference evapotranspiration and crop coefficients (developed during 2015-16) for different models during 2017-18

\begin{tabular}{|c|c|c|c|c|c|c|c|c|c|}
\hline \multicolumn{10}{|c|}{ Estimated ET $(\mathrm{mm})$} \\
\hline $\begin{array}{l}\text { Crop } \\
\text { period }\end{array}$ & $\begin{array}{l}\text { Actual } \\
\text { ET } \\
(\mathrm{mm}) \\
\end{array}$ & $\begin{array}{l}\text { Penman } \\
\text { Monteith }\end{array}$ & $\begin{array}{l}\text { Advection- } \\
\text { Aridity } \\
\text { model } \\
\end{array}$ & $\begin{array}{l}\text { Granger- } \\
\text { Gray } \\
\text { model }\end{array}$ & Makkink & $\begin{array}{l}\text { Blaney- } \\
\text { Criddle }\end{array}$ & $\begin{array}{l}\text { Turc } \\
(1961)\end{array}$ & $\begin{array}{l}\text { Hargreaves- } \\
\text { Samani }\end{array}$ & $\begin{array}{l}\text { Priestly- } \\
\text { Tailor }\end{array}$ \\
\hline $\begin{array}{l}\text { Initial period } \\
\text { (0-13 DAS) }\end{array}$ & 27.96 & $\begin{array}{l}27.74 \\
(-0.79 \%)^{*}\end{array}$ & $\begin{array}{l}28.12 \\
(0.57 \%)\end{array}$ & $\begin{array}{l}29.89 \\
(6.90 \%)\end{array}$ & $\begin{array}{l}27.74 \\
(-0.79 \%)\end{array}$ & $\begin{array}{l}27.30 \\
(-2.36 \%)\end{array}$ & $\begin{array}{l}25.91 \\
(-7.33 \%)\end{array}$ & $\begin{array}{l}26.42 \\
(-5.51 \%)\end{array}$ & $\begin{array}{l}27.73 \\
(-0.82 \%)\end{array}$ \\
\hline $\begin{array}{l}\text { Development } \\
\text { period } \\
(14-33 \text { DAS })\end{array}$ & 36.90 & $\begin{array}{l}38.05 \\
(3.12 \%)\end{array}$ & $\begin{array}{l}36.65 \\
(-0.68 \%)\end{array}$ & $\begin{array}{l}36.20 \\
(-1.90 \%)\end{array}$ & $\begin{array}{l}37.72 \\
(2.22 \%)\end{array}$ & $\begin{array}{l}36.84 \\
(-0.16 \%)\end{array}$ & $\begin{array}{l}33.94 \\
(-8.02 \%)\end{array}$ & $\begin{array}{l}36.63 \\
(-0.73 \%)\end{array}$ & $\begin{array}{l}38.60 \\
(4.61 \%)\end{array}$ \\
\hline $\begin{array}{l}\text { Mid period } \\
(34-65 \text { DAS) }\end{array}$ & 61.86 & $\begin{array}{l}61.02 \\
(-1.36 \%)\end{array}$ & $\begin{array}{l}55.60 \\
(-10.12 \%)\end{array}$ & $\begin{array}{l}53.35 \\
(-13.76 \%)\end{array}$ & $\begin{array}{l}61.99 \\
(0.21 \%)\end{array}$ & $\begin{array}{l}56.03 \\
(-9.42 \%)\end{array}$ & $\begin{array}{l}53.62 \\
(-13.32 \%)\end{array}$ & $\begin{array}{l}64.16 \\
(3.72 \%)\end{array}$ & $\begin{array}{l}62.58 \\
(1.16 \%)\end{array}$ \\
\hline $\begin{array}{l}\text { Late period } \\
\text { (66-93 DAS) }\end{array}$ & 42.41 & $\begin{array}{l}42.05 \\
(-0.85 \%)\end{array}$ & $\begin{array}{l}39.17 \\
(-7.64 \%)\end{array}$ & $\begin{array}{l}38.73 \\
(-8.68 \%)\end{array}$ & $\begin{array}{l}42.83 \\
(0.99 \%)\end{array}$ & $\begin{array}{l}39.20 \\
(-7.57 \%)\end{array}$ & $\begin{array}{l}38.12 \\
(-10.375)\end{array}$ & $\begin{array}{l}40.24 \\
(-5.12 \%)\end{array}$ & $\begin{array}{l}42.53 \\
(0.28 \%)\end{array}$ \\
\hline Total & 169.13 & $\begin{array}{l}168.86 \\
(-0.16 \%)\end{array}$ & $\begin{array}{l}159.54 \\
(-5.67 \%)\end{array}$ & $\begin{array}{l}158.17 \\
(-6.47 \%)\end{array}$ & $\begin{array}{l}170.28 \\
(0.68 \%)\end{array}$ & $\begin{array}{l}159.37 \\
(-5.77 \%)\end{array}$ & $\begin{array}{l}151.59 \\
(-10.37 \%)\end{array}$ & $\begin{array}{l}167.45 \\
(-0.99 \%)\end{array}$ & $\begin{array}{l}171.44 \\
(1.37 \%)\end{array}$ \\
\hline
\end{tabular}

* Data within parenthesis indicates average error

Table 4:Error analysis of ET estimation by different models

\begin{tabular}{lllllllll}
\hline Parameters & $\begin{array}{l}\text { Penman } \\
\text { Monteith }\end{array}$ & $\begin{array}{l}\text { Advection- } \\
\text { Aridity } \\
\text { model }\end{array}$ & $\begin{array}{l}\text { Granger- } \\
\text { Gray } \\
\text { model }\end{array}$ & Makkink & $\begin{array}{l}\text { Blaney- } \\
\text { Criddle }\end{array}$ & $\begin{array}{l}\text { Turc } \\
(1961)\end{array}$ & $\begin{array}{l}\text { Hargreaves- } \\
\text { Samani }\end{array}$ & $\begin{array}{l}\text { Priestly- } \\
\text { Tailor }\end{array}$ \\
\hline MAE $(\mathrm{mm})$ & 0.08 & 0.15 & 0.18 & 0.20 & 0.21 & 0.20 & 0.23 & 0.08 \\
MBE $(\mathrm{mm})$ & -0.003 & -0.10 & -0.12 & 0.01 & -0.10 & -0.19 & -0.02 & 0.02 \\
RMSE $(\mathrm{mm})$ & 0.11 & 0.19 & 0.22 & 0.24 & 0.27 & 0.24 & 0.29 & 0.11 \\
\hline
\end{tabular}

\section{CONCLUSION}

The investigation was carried out to determine the crop coefficients $(\mathrm{Kc})$ and estimate evapotranspiration of rapeseed using lysimeter and eight reference evapotranspiration models. The study revealed that estimated evapotranspiration using Penman-Monteith reference gave the best estimate of evapotranspiration of rapeseed followed by Priestly-Tailor. During the initial stage of the crops, the evapotranspiration was less and increased during the development stage, reached its maximum values during mid-season and reduced during crop maturation stages. The crop coefficients for initial, mid and end stages were $0.83,1.20$ and 0.65 , respectively for Penman-Monteith and $0.70,1.05$ and 0.55 , respectively for Priestly-Tailor. The information generated can be used in scheduling irrigation for rapeseedin Jorhat. 


\section{REFERENCES}

Allen, R.G. and Pruitt, W.O. (1986). Rational use of the FAO Blaney-Criddle formula. J. Irrig. Drain. Engg., 112 (2): 139-155.

Allen, R.G., Pereira, L., Raes, D. and Smith, M. (1998). Crop evapotranspiration: Guidelines for computing crop water requirements. Irrigation and Drainage Paper 24, FAO of the United Nations, Rome. 300 p.

Bhat, S.A., Pandit, B., Dar, M.U.D.,Ali, S.R., Jan, R. and Khan, S. (2017). Comparative study of different methods of evapotranspiration estimation in Kashmir Valley. $J$. Agrometeorol., 19(4): 383-384.

Bhavsar,P.N. and Patel, J.N. (2016). Development of relationship between crop coefficient and NDVI using geospatial technology. J. Agrometeorol., 18(2): 261-264.

Brutsaert, W. and Strickler, H. (1979). An advection-aridity approach to estimate actual regional evapotranspiration. Water Resourc. Res., 15: 443-449.

Dar, E.A., Yousuf, A. and Brar, A.S. (2017). Comparison and evaluation of selected evapotranspiration models for Ludhiana district of Punjab. J. Agrometeorol., 19(3): 274-276.

deBruin, H.A.R.(1981). The determination of(reference crop) evapotranspiration from routine weather data. Proceedings of Technical Meeting 38. Committee for Hydrological Research TNO, Evaporation in relation to hydrology. Proc. Inf., 28: 25-37.

Doorenbos, J. and W.O., Pruitt, (1977). Guidelines for predicting crop water requirements. Irrig. and Drain. PaperNo. 24, 2nded., Food Agric. Org., United Nations, Rome. FAO. Agriculture, food and water, Rome, Italy.

Granger, R.J. and Gray, D.M. (1989). Evaporation from natural nonsaturated surfaces. J. Hydrol., 111: 21-29.

Hargreaves, G.H. and Samani, Z.A. (1985). Reference crop evapotranspiration from temperature. Applied Engg. Agric., 1: 96-99.

Incrocci, L., Marzialetti, P., Incrocci, G. and Di Vita, A. (2014). Substrate water status and evapotranspiration irrigation scheduling in heterogenous container nursery crops. Agric. Water Manage., 131:28-42.

Khavse, R., Chaudhary, J.L., and Bhelawe, S. (2017). Comparison of different methods for evaluating potential evapotranspiration in Chhattisgarh. J. Agrometeorol., 19(1): 90-92.
Kokilavani, S., Panneerselvam, S., Dheebakaran, G.A. and Balasubramanian, T.N. (2018) Crop water requirement (ETc) of sorghum at Coimbatore. J. Agrometeorol., 20(4): 345-346.

Mehta, R. and Pandey, V. (2016). Crop water requirement (ETc) of different crops of middle Gujarat. J. Agrometeorol., $18(1): 83-87$.

Naidu, D. and Majhi, B. (2019). Reference evapotranspiration modelling using radial basis function neural network in different agro-climatic zones of Chhattisgarh. $J$. Agrometeorol., 21(3): 316-326.

Phad, S.V., Dakhore, K.K. and Sayyad, R.S. (2019). Comparison of different methods for estimation of reference evapotranspiration at Parbhani, Maharashtra. $J$. Agrometeorol., 21(2): 236-238.

Prajapati, G.V. and Subbaiah, R. (2019). Crop coefficients of Bt. cotton under variable moisture regimes and mulching. $J$. Agrometeorol., 21(2): 166-170.

Priestley, C.H.B. and Taylor, R.J. (1972). On the assessment of surface heat flux and evaporation using large scale parameters. Mon. Weath. Review., 100: 81-92.

Ragab, R., Evans, J.G., Battilani, A. and Solimando, D. (2017).Towards accurate estimation of crop water requirement without the crop coefficient: New approach using modern technologies. Irrig. Drain., 66: 469-477.

Sarma,A. andDas, J.C. (2017). Irrigation and fertilizereffects on productivity, quality, water use and economics of Yellow Sarson [B. rapa (L.) var. trilocularis]. J. Oilseed Brassica 8(1): $72-79$.

Tahashildar, M., Bora, P.K., Ray, L.I.P. and Thakuria, D. (2017). Comparison of different reference evapotranspiration (ET0) models and determination of crop-coefficients of french bean (Phesiolus vulgaris.) in mid hill region of Meghalaya. J. Agrometeorol., 19(3): 233-237.

Tomar, A.S. (2016). Performance of radiation based reference evapotranspiration equation developed for Indian subhumid conditions. J. Agrometeorol., 18(1):76-82.

Turc, L. (1961). Estimation of irrigation water requirements, potential evapotranspiration: A simple climatic formula evolved up to date. Annu. Agron., 12: 13-49. 